\title{
Therapeutic Bio-Compounds from Avocado Residual Biomass ${ }^{\dagger}$
}

\author{
Minerva C. García-Vargas 1,*,‡, María del Mar Contreras 2,3,*, and Eulogio Castro 2,3 \\ 1 Tecnológico Nacional de México/Instituto Tecnológico de Zitácuaro, 61534 Zitácuaro, Michoacán, Mexico \\ 2 Department of Chemical, Environmental and Materials Engineering, Universidad de Jaén, 23071 Jaén, Spain; \\ ecastro@ujaen.es \\ 3 Centro de Estudios Avanzados en Ciencias de la Tierra, Energía y Medio Ambiente (CEACTEMA), \\ Universidad de Jaén, 23071 Jaén, Spain \\ * Correspondence: minerva.gv@zitacuaro.tecnm.mx (M.C.G.-V.); mcgamez@ujaen.es or \\ mmcontreras@ugr.es (M.d.M.C.) \\ + Presented at the 1st International Electronic Conference on Biomolecules: Natural and Bio-Inspired \\ Therapeutics for Human Diseases, 1-13 December 2020; Available online: https://iecbm2020.sciforum.net/. \\ $\ddagger$ Both authors contribute equally.
}

Citation: García-Vargas, M.C.; Contreras, M.d.M.; Castro, E. Therapeutic Bio-Compounds from Avocado Residual Biomass.

Proceedings 2021, 79, 4. https:// doi.org/10.3390/IECBM2020-08656

Published: 1 December 2020

Publisher's Note: MDPI stays neutral with regard to jurisdictional claims in published maps and institutional affiliations.

Copyright: (c) 2020 by the authors. Licensee MDPI, Basel, Switzerland. This article is an open access article distributed under the terms and conditions of the Creative Commons Attribution (CC BY) license (http://creativecommons.org/licenses /by/4.0/).

\begin{abstract}
Since ancient times, plants have been used as preservatives, spices, flavorings and as natural remedies to prevent or treat diseases owing to the biological activity correlated with the bioactive compounds they contain. The avocado fruit (Persea americana), native to Mexico and Guatemala, has been traditionally used for its pleasant organoleptic characteristics, high nutritional value and health benefits, but its residual biomass (seeds, skin and tree leaves) is also valuable in therapeutic terms. For this reason, the present investigation reviews the pharmacological potential of avocado waste. It can serve as a source of antioxidants, as well as hypotensive, anti-analgesic, photoprotective, antibacterial, and anti-inflammatory agents, and can be used to treat skin disorders. The main active components seem to be phenolic compounds. The content of phenolic compounds in waste extracts varied from 6 to $307 \mathrm{~g} / \mathrm{kg}$ dry weight, depending on the waste type and extraction conditions, among others. In particular, our results suggested that using water as a solvent, a high amount of phenolic compounds can be obtained from the peel ( $266 \mathrm{~g} / \mathrm{kg}$ dry weight), and this was correlated with major antioxidant activity. Therefore, the peels can be applied to obtain antioxidants, and water can be used as an environmentally friendly extraction solvent to obtain various valuable compounds of its chemical composition for food and pharmacological applications.
\end{abstract}

Keywords: avocado seed; avocado peel; Persea americana extracts; anti-inflammatory

\section{Introduction}

Since ancient times, plants have been used as spices, preservatives, flavorings and as natural remedies to prevent or treat diseases owing to the biological activity correlated with the active compounds they contain. The use of natural extracts with pharmacological activity is of great interest because they have therapeutic potential in the treatment of different diseases with fewer side effects. The avocado is a fruit that has become fashionable for its attractive organoleptic characteristics, high nutritional value and health benefits. It is consumed as a fresh product and is also processed to obtain salad oil and guacamole. In both cases, the only usable portion is the pulp. However, the inedible parts have been consumed as remedies, for example, by the Mayans and Aztecs. In particular, the leaf has been used for expelling intestinal parasites, in gynecological and gastrointestinal problems, etc. [1,2]. Currently, a large number of studies are being carried out on the properties not only of the avocado pulp but also of the fruit seed, the fruit peel and the tree's leaves. Pharmacological actions such as antioxidant activity; hypotensive, anti-analgesic and anti-inflammatory effects; skin disorder treatment; photoprotective 
effects against UVB radiation; antiviral, antifungal and antioxidant actions, etc. are being related to their bioactive compounds, such as phenolic compounds $[3,4]$. Therefore, besides avocado fruit and oil, avocado waste extracts could promote the development of functional ingredients for applications in the food, nutraceutical, pharmaceutical and cosmetic sectors.

\section{Methods}

Bibliographic research was carried out for finding and accessing reviews, articles in academic journals, institutional repositories, archives using databases and search engines. Most recent literature was selected (mainly since the last five years).

Additionally, experimental research was performed: avocado residues were obtained from the fruit cultivar "Hass". The peel and stones were dried at room temperature and exposed to crushing by a $1.0 \mathrm{~mm}$ material at Retsch ZM200 Mill (Hann, Germany). The samples were subjected to Soxhlet extraction for $24 \mathrm{~h}$ with water, and then the residual solid fraction was extracted with ethanol. Aqueous and ethanolic extracts were filtered before analysis (nylon filters of $0.45 \mu \mathrm{m}$ pore size) (SinerLab Group, Madrid, Spain). The total phenolic content (TPC) was measured using the Folin-Ciocalteu colorimetric assay, its absorbance was measured with a microplate reader (Bio-Rad iMark $^{\mathrm{TM}}$, Hercules, CA, USA) at $655 \mathrm{~nm}$. The TPC was reported as g gallic acid equivalent (GAE)/kg of extract by using a gallic acid calibration curve. The total flavonoid content (TFC) was determined using the aluminum chloride colorimetric method; absorbance was measured with the aforementioned microplate reader at $510 \mathrm{~nm}$. The total flavonoid content was calculated from a calibration curve built with rutin, and the results were expressed as g rutin equivalent (RE) per $\mathrm{kg}$ of extract.

The antioxidant activity was appraised by the antioxidant ability of avocado peel and stones to reduce the cation ABTS ${ }^{\bullet+}$ and $\mathrm{Fe}^{3+}$ using the ABTSTM (2,2'-azino-bis(3-ethylbenzothiazoline-6-sulfonic acid) radical scavenging and ferric reducing antioxidant power (FRAP) assays. The absorbance was measured with Bio-Rad iMarkTM at $734 \mathrm{~nm}$ for TEAC. Absorbance readings of the antioxidant extracts were compared to standard calibration curves of the hydrophilic vitamin $\mathrm{E}$ analog, Trolox (6-330 $\mu \mathrm{M})$, and the results were expressed as $\mathrm{g}$ Trolox equivalents (TE) per $\mathrm{kg}$ of extract.

\section{Results and Discussion}

\subsection{Bioactive Properties}

An excellent opportunity to take advantage of the rich sources of natural compounds for therapeutic purposes is agro-industrial waste. In recent years, the number of studies characterizing the composition of avocado peel, stones and leaves has increased in order to explore the possibility of using them as a value-added product in the pharmaceutical industry. Some of the pharmacological actions that have been published are cancer inhibitory activity; moderate activity against epimastigotes and trypomastigotes; as an inhibitor of the growth of fungi, yeasts, bacteria and viruses; as a potential antidiabetic agent, etc. Table 1 depicts a summary of these biological properties.

Table 1. Pharmacological properties of avocado peel, stone and leaf extracts.

\begin{tabular}{|c|c|c|c|c|}
\hline Avocado Part & Pharmacological Action & Bio-Compound & Study Type a & Ref. \\
\hline Stone & Antioxidant and cancer inhibitory activity & Polyphenols & IVT & {$[5]$} \\
\hline Stone & $\begin{array}{c}\text { Moderate activity against epimastigotes and } \\
\text { trypomastigotes }\end{array}$ & $\begin{array}{l}\text { trihydroxyheptadecane and } \\
\text { trihydroxy-nonadecane derivatives }\end{array}$ & IVT & [6] \\
\hline Stone and leaf & $\begin{array}{l}\text { Pro-apoptotic effect on Jurkat lymphoblastic leukemia } \\
\text { cells that are eliminated through an oxidative stress } \\
\text { mechanism }\end{array}$ & ( & IVT & [7] \\
\hline Peel & $\begin{array}{c}\text { Antibacterial activity against a wide range of } \\
\text { infectious agents }\end{array}$ & $\begin{array}{l}\text { Phenolic compounds } \\
\text { Alkaloids }\end{array}$ & IVT & [8] \\
\hline
\end{tabular}


Anti-oxidative properties

Antimicrobial properties, including fungi, yeasts, bacteria, and viruses

Antinociceptive effect on UVB radiation-induced skin

Leaf injury in mice. Treatment of the pain associated with sunburn

Phenolic compounds such as

(+)-catechin, chlorogenic acid and rutin

IVV

[9]

Phenolic compounds, including phenolic acids and flavonoids

IVT

Leaf

Antioxidant activity

Perseorangin

IVT

${ }^{\text {a }}$ In vitro (IVT), in vivo (IVV), and in humans (H).

Most of the in vitro investigations consulted in this work agree that avocado stones, peel and leaves have antioxidant properties, owing to the phenolic compounds present in their constitution. Owing to these biocompounds, they are capable of reducing or inhibiting oxidation reactions. Although antioxidants can be obtained synthetically, the trend is to obtain them from natural sources to avoid possible toxic effects in humans. Table 2 shows a summary of studies that have reported the antioxidant properties of the avocado waste extracts. It also highlights that there is a high variability between the antioxidant activity values reported, even for the same cultivar, and depending on the extraction method and plant part. Among the solvents applied, water can be applied to recover antioxidant compounds from the peel. Our preliminary results show that it was possible to extract around $87 \%$ of the total content when water and ethanol were sequentially applied. Moreover, microwave-assisted extraction using aqueous solutions of acetone and ethanol showed high TPC and antioxidant activity.

Table 2. Total phenolic content (TPC), total flavonoid content (TFC) and antioxidant activity determined by the ABTS and ferric reducing antioxidant power (FRAP) assays.

\begin{tabular}{|c|c|c|c|c|c|c|c|}
\hline Part & Extraction Method & Solvent & $\begin{array}{c}\text { TPC } \\
\text { (g GAE/kg) }\end{array}$ & $\begin{array}{c}\text { TFC } \\
\text { (g RE/kg) } \\
\end{array}$ & $\begin{array}{c}\text { ABTS } \\
\text { (g TE/kg) }\end{array}$ & $\begin{array}{c}\text { FRAP } \\
(\mathrm{g} \text { TE/kg) }\end{array}$ & Ref. \\
\hline \multirow{8}{*}{ Peel } & Soxhlet extraction & Water & 266 & 342 & 281 & 245 & This study \\
\hline & Boiling & Water & 20 & 11 & ND & 23 & [12] \\
\hline & $\begin{array}{c}\text { Ultrasound-assisted } \\
\text { extraction }\end{array}$ & $80 \%$ Ethanol & 64 & ND & 198 & ND & [13] \\
\hline & Homogenization & $70 \%$ Acetone & 90 & ND & ND & ND & {$[14]$} \\
\hline & Homogenization & 70\% Acetone & 51 & ND & ND & ND & [15] \\
\hline & Stirring in bath & $50 \%$ Ethanol & 31 & ND & 66 & 110 & [16] \\
\hline & Homogenization & $\begin{array}{c}50 \% \text { Methanol and } \\
70 \% \text { acetone }\end{array}$ & 137 & ND & ND & 137 & [17] \\
\hline & Heated and filtered & Water & 52 & 2 & ND & ND & [8] \\
\hline \multirow{9}{*}{ Stone } & Soxhlet extraction & Water & 18 & 27 & 25 & 19 & This study \\
\hline & Boiling & Water & 6 & 3 & ND & 10 & [12] \\
\hline & $\begin{array}{c}\text { Ultrasound-assisted } \\
\text { extraction }\end{array}$ & $80 \%$ Ethanol & 57 & ND & 162 & ND & [13] \\
\hline & $\begin{array}{l}\text { Acelerated solvent } \\
\text { extraction }\end{array}$ & $50 \%$ Ethanol & ND & ND & 88 & ND & [18] \\
\hline & Homogenization & $70 \%$ Acetone & 61 & ND & ND & ND & [19] \\
\hline & Homogenization & $70 \%$ Acetone & 41 & ND & ND & ND & [15] \\
\hline & Homogenization & $\begin{array}{c}50 \% \text { methanol and } \\
70 \% \text { acetone }\end{array}$ & 81 & & ND & 77 & [17] \\
\hline & $\begin{array}{c}\text { Microwave-assisted } \\
\text { extraction }\end{array}$ & $70 \%$ Acetone & 307 & ND & 607 & ND & [20] \\
\hline & $\begin{array}{c}\text { Microwave-assisted } \\
\text { extraction }\end{array}$ & $58.5 \%$ Ethanol & 254 & ND & 516 & ND & [20] \\
\hline
\end{tabular}

GAE, gallic acid equivalents; RE, rutin equivalents; TE, Trolox equivalents. 


\subsection{Phytochemicals}

Phenolic compounds are some of the active components of avocado waste (Tables 1 and 2). The chemical structure of these natural compounds found in avocado is summarized in Figure 1.

In addition, the structure of a natural colorant (glycosylated benzotropolone) has recently been identified in the stones, and it showed anti-inflammatory activity $[3,11,21]$ (Figure 2). The active fractions with trypanocidal activity against Trypanosoma cruzi, the etiological agent for Chagas' diseases, included 1,2,4-trihydroxyheptadecane and 1,2,4-trihydroxynonadecane derivatives [6] (Figure 2).

Phenolic alcohol and derivatives<smiles>OCCc1ccc(O)c(O)c1</smiles>

$\mathrm{P}$ and $\mathrm{S}$

Flavones<smiles>O=c1cc(-c2ccc(O)cc2)oc2cc(O)cc(O)c12</smiles>

$P, S$ and $L$

Flavan-3-ols monomers<smiles>Oc1cc(O)c2c(c1)OC(c1ccc(O)c(O)c1)C(O)C2</smiles>

$\mathrm{P}, \mathrm{S}$ and $\mathrm{L}$

\section{Flavonols}<smiles>O=c1c(O)c(-c2ccc(O)c(O)c2)oc2cc(O)cc(O)c12</smiles>

$\mathrm{P}, \mathrm{S}$ and $\mathrm{L}$

Flavanone<smiles>O=C1C[C@H](c2ccc(O)cc2)Oc2cc(O)cc(O)c21</smiles>

$P$ and $S$

Procyanidins<smiles>CCCCC(C)(C)C(C)(C)C</smiles>

$\mathrm{P}$ and $\mathrm{S}$

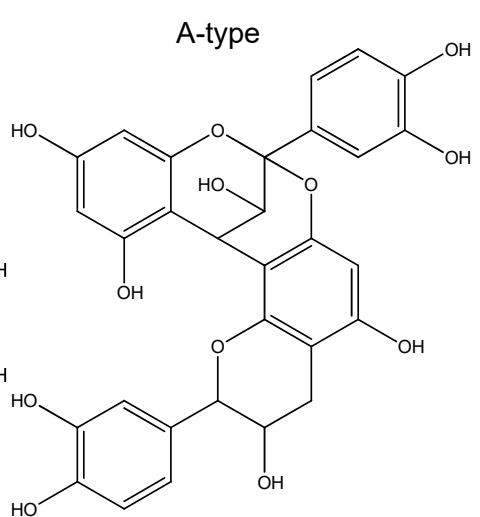

S

Figure 1. Phenolic classes found in avocado waste, peel (P), stone (S), leaf (L) and example of the structures: hydroxytyrosol (phenolic alcohol), quercetin (flavonol), apigenin (flavone), naringenin (flavanone), (epi)catechin (flavan-3-ols monomer), and B- and A-type flavan-3-ols dimers (procyanidins). 


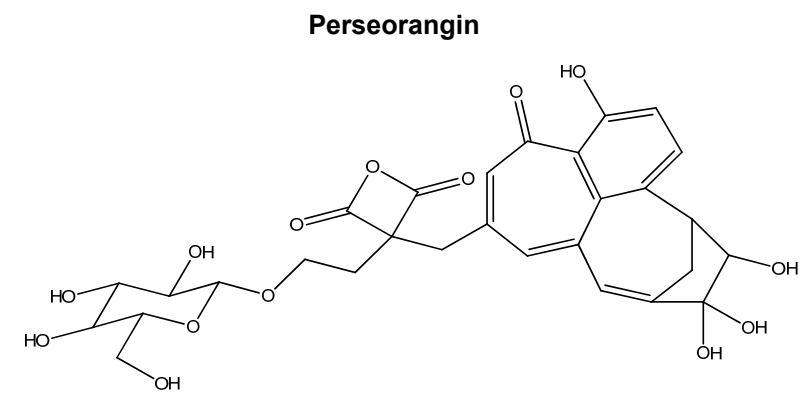

1,2,4-Trihydroxyheptadecane derivatives
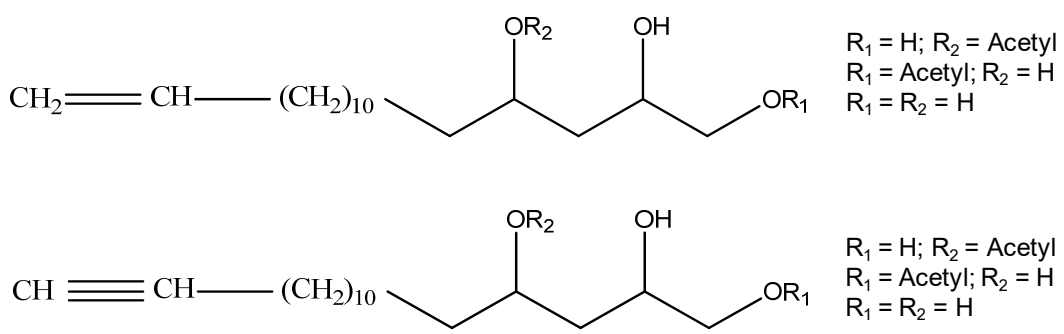

1,2,4-Trihydroxynonadecane derivative<smiles>CCCCCCCCCCCC/C=C/CC(O)CC(O)CO</smiles>

Figure 2. Other phytochemicals characterized in the avocado stone extracts with bioactive properties.

\section{Conclusions}

In vitro and in vivo studies suggest that avocado waste possesses bioactive properties. Phenolic compounds are generally the antioxidant compounds found in the extracts, but other phytochemicals have been identified in active extracts with anti-inflammatory and trypanocidal activity, including a glycosylated benzotropolone and trihydroxyheptadecane and trihydroxynonadecane derivatives. Nonetheless, further in vivo and clinical studies are required to confirm these studies.

Acknowledgments: The authors thank the FEDER UJA project 1260905 funded by "Programa Operativo FEDER 2014-2020" and "Consejería de Economía y Conocimiento de la Junta de Andalucía". M.C.G.V. thanks the grant "Beca-comisión para estadía técnica del Tecnológico Nacional de México/Instituto Tecnológico de Zitácuaro y Universidad de Jaén”.

Institutional Review Board Statement: Not applicable.

Informed Consent Statement: Not applicable.

Data Availability Statement: Data are available on request from the corresponding authors.

Conflicts of Interest: The authors declare no conflict of interest.

\section{References}

1. Gutiérrez, M.L.; Villanueva, M. The avocado in the prehispanic time avocados in the prehispanic time. In Proceedings of the VI World Avocado Congress, Viña Del Mar, Chile, 12-16 November 2007.

2. Dabas, D.; Elias, R.J.; Lambert, J.D.; Ziegler, G.R. A Colored Avocado Seed Extract as a Potential Natural Colorant. J. Food Sci. 2011, 76, 1335-1341, doi:10.1111/j.1750-3841.2011.02415.x.

3. Dabas, D.; Ziegler, G.R.; Lambert, J.D. Anti-Inflammatory Properties of a Colored Avocado Seed Extract. Adv. Food Technol. Nutr. Sci. Open J. 2019, 5, 8-12, doi:10.17140/aftnsoj-5-151. 
4. Bhuyan, D.J.; Alsherbiny, M.A.; Perera, S.; Low, M.; Basu, A.; Devi, O.A.; Barooah, M.S.; Li, C.G.; Papoutsis, K. The odyssey of bioactive compounds in Avocado (Persea Americana) and their health benefits. Antioxidants 2019, 8, 426, doi:10.3390/antiox8100426.

5. Dabas, D.; Elias, R.J.; Ziegler, G.R.; Lambert, J.D. In vitro antioxidant and cancer inhibitory activity of a colored avocado seed extract. Int. J. Food Sci. 2019, 2019, 6509421, doi:10.1155/2019/6509421.

6. Abe, F.; Nagafuji, S.; Okawa, M.; Kinjo, J.; Akahane, H.; Ogura, T.; Martinez-Alfaro, M.A.; Reyes-Chilpa, R. Trypanocidal constituents in plants 5. Evaluation of some Mexican plants for their trypanocidal activity and active constituents in the seeds of Persea americana. Biol. Pharm. Bull. 2005, 28, 1314-1317, doi:10.1248/bpb.28.1314.

7. Bonilla-Porras, A.R.; Salazar-Ospina, A.; Jimenez-Del-Rio, M.; Pereañez-Jimenez, A.; Velez-Pardo, C. Pro-apoptotic effect of Persea americana var. Hass (avocado) on Jurkat lymphoblastic leukemia cells. Pharm. Biol. 2014, 52, 458-465, doi:10.3109/13880209.2013.842599.

8. Kamaraj, M.; Dhana Rangesh Kumar, V.; Nithya, T.G.; Danya, U. Assessment of antioxidant, antibacterial activity and phytoactive compounds of aqueous extracts of avocado fruit peel from Ethiopia. Int. J. Pept. Res. Ther. 2020, 26, 1549-1557, doi:10.1007/s10989-019-09965-6.

9. Deuschle, V.C.K.N.; Brusco, I.; Piana, M.; Faccin, H.; de Carvalho, L.M.; Oliveira, S.M.; Viana, C. Persea americana Mill. crude extract exhibits antinociceptive effect on UVB radiation-induced skin injury in mice. Inflammopharmacology 2019, 27, 323-338, doi:10.1007/s10787-018-0441-9.

10. Castro-López, C.; Bautista-Hernández, I.; González-Hernández, M.D.; Martínez-Ávila, G.C.G.; Rojas, R.; Gutiérrez-Díez, A.; Medina-Herrera, N.; Aguirre-Arzola, V.E. Polyphenolic profile and antioxidant activity of leaf purified hydroalcoholic extracts from seven mexican Persea americana cultivars. Molecules 2019, 24, 173, doi:10.3390/molecules24010173.

11. Salazar-Lópeza, N.J.; Domínguez-Avila, A.; Yahia, E.M.; Belmonte-Herrera, B.H.; Wall-Medrano, A.; Montalvo-González, E.; González-Aguilar, G.A. Avocado fruit and by-products as potential sources of bioactive compounds. Food Res. Int. 2020, 138, 109774, doi:10.1016/j.foodres.2020.109774.

12. Calderón-Oliver, M.; Escalona-Buendía, H.B.; Medina-Campos, O.N.; Pedraza-Chaverri, J.; Pedroza-Islas, R.; Ponce-Alquicira, E. Optimization of the antioxidant and antimicrobial response of the combined effect of nisin and avocado byproducts. LWT Food Sci. Technol. 2016, 65, 46-52, doi:10.1016/j.lwt.2015.07.048.

13. Daiuto, É.R.; Tremocoldi, M.A.; Matias De Alencar, S.; Vieites, R.L.; Minarelli, P.H. Chemical composition and antioxidant activity of the pulp, peel and by products of avocado 'hass. Rev. Bras. Frutic. 2014, 36, 417-424, doi:10.1590/0100-2945-102/13.

14. Rodríguez-Carpena, J.G.; Morcuende, D.; Petrón, M.J.; Estévez, M. Inhibition of cholesterol oxidation products (COPs) formation in emulsified porcine patties by phenolic-rich avocado (Persea americana Mill.) extracts. J. Agric. Food Chem. 2012, 60, 2224-2230, doi:10.1021/jf2040753.

15. Saavedra, J.; Córdova, A.; Navarro, R.; Díaz-Calderón, P.; Fuentealba, C.; Astudillo-Castro, C.; Toledo, L.; Enrione, J.; Galvez, L. Industrial avocado waste: Functional compounds preservation by convective drying process. J. Food Eng. 2017, 198, 81-90, doi:10.1016/j.jfoodeng.2016.11.018.

16. Segovia, F.J.; Hidalgo, G.I.; Villasante, J.; Ramis, X.; Almajano, M.P. Avocado seed: A comparative study of antioxidant content and capacity in protecting oil models from oxidation. Molecules 2018, 23, 2421, doi:10.3390/molecules23102421.

17. Permal, R.; Leong Chang, W.; Seale, B.; Hamid, N.; Kam, R. Converting industrial organic waste from the cold-pressed avocado oil production line into a potential food preservative. Food Chem. 2020, 306, 125635, doi:10.1016/j.foodchem.2019.125635.

18. Figueroa, J.G.; Borrás-Linares, I.; Lozano-Sánchez, J.; Segura-Carretero, A. omprehensive characterization of phenolic and other polar compounds in the seed and seed coat of avocado by HPLC-DAD-ESI-QTOF-MS. Food Res. Int. 2018, 105, 752-763, doi:10.1016/j.foodres.2017.11.082..

19. Rodríguez-Carpena, J.G.; Morcuende, D.; Estévez, M. Avocado by-products as inhibitors of color deterioration and lipid and protein oxidation in raw porcine patties subjected to chilled storage. Meat Sci. 2011, 89, 166-173, doi:10.1016/j.meatsci.2011.04.013.

20. Araújo, R.G.; Rodriguez-Jasso, R.M.; Ruiz, H.A.; Govea-Salas, M.; Pintado, M.E.; Aguilar, C.N. Process optimization of microwave-assisted extraction of bioactive molecules from avocado seeds. Ind. Crops Prod. 2020, 154, 112623, doi:10.1016/j.indcrop.2020.112623.

21. Hatzakis, E.; Mazzola, E.P.; Shegog, R.M.; Ziegler, G.R.; Lambert, J.D. Perseorangin: A natural pigment from avocado (Persea americana) seed. Food Chem. 2019, 293, 15-22, doi:10.1016/j.foodchem.2019.04.064. 